\title{
Dinamisme Sekuensial Pada Komik Gundala Karya Hasmi
}

\author{
Terra Bajraghosa \\ Staf Pengajar \\ Program Studi Disain Komunikasi Visual ISI Yogyakarta \\ bajraghosa@gmail.com
}

\begin{abstract}
This research is a comic study, focus on Indonesian comic, especially on Gundala Putra Petir series, created by Harya Suraminata (Hasmi). The study will be narrowed, examining some spesific panels inside 'Gundala Cuci nama' and 'Dr. Jaka dan Ki Wilawuk' series. This research intended to seek what are sequential dynamisms look like on Gundala comicbook, and what kind of relations between sequential dynamism and Gundala narratology have.

Andre Molotiu's approach about Sequential Dynamism on abstract comic is applied in this research, focusing on the relation to narratology. This research contributing in Indonesian comic studies by offering different method, and having hope that in the near future there are more publication of Indonesia comic books that pay attention more to sequential dynamism.
\end{abstract}

Keywords: Comic book, Gundala, Sequential Dynamism

Relevance to Visual Communication Design Practice: Sequential dynamism is an actual and practical application of elementary design method in the field of comic as a visual communication medium.

\section{PENDAHULUAN}

Perkembangan terkini skena komik Indonesia cukup menjanjikan baik dari segi industri maupun artistik, bila dibandingkan 10 tahun yang lalu ketika hanya ada satu atau dua penerbit yang berani menerbitkan komik Indonesia. Salah satu unsur penceritaanvisual dalam komik adalah hadirnya panelpanel secara sekuensial pada tiap-tiap halaman komik. Sifat sekuensial ini merupakan hal penting dalam kreasi komik, yang membedakannya dengan karya ilustrasi dan animasi. Jika ilustrasi bersifat statis, sebagai sebuah penjelas karya sastra-tekstual, komik bersifat sekuensial yang menempatkan urutan sebagai dasar untuk jalannya cerita. Di dalam menata komposisi karya komik, karakter sekuensial ini bisa dihadirkan dengan suatu proses yang disebut enkapsulasi. Proses komposisi yang disebut encapsulation atau enkapsulasi, memerlukan keputusan yang kreatif dan merupakan proses penting dalam komunikasi komik, yang esensial dan unik dalam penciptaan suatu pesan dalam komik. Cerita dalam komik tidak ditampilkan utuh semua bagiannya dalam bentuk verbal maupun visual, dan tidak ditampilkan semua aksinya dalam bentuk naratif. Komikus atau penulis harus memutuskan citra (kata dan gambar) tertentu 
yang harus ditunjukkan untuk Filosofi (Duncan \& Smith 2012: 1). menyampaikan cerita. Momen aksi utama Pendekatan-pendekatan inilah yang tertentu akan dipilih oleh penulis atau digunakan untuk menelaah komik, yang juga komikus untuk ditampilkan dalam suatu ruang khusus, suatu unit dalam komunikasi komik, yang disebut panel (Duncan \& Smith, 2009: 120-125). Pemilihan sekuens kejadian untuk dienkapsulasikan sangat penting, karena beberapa rangkaian panel dapat berinteraksi untuk membentuk suatu makna tertentu, yang mungkin tidak ada di panel tunggal. Pemilihan suatu momen, dan berapa banyak yang hendak ditampilkan dalam panel-panel, menentukan keberhasilan pemahaman atas sebuah halaman komik yang bekerja sebagai satu unit (Duncan \& Smith, 2009: 125-127).

Meningkatnya apresiasi atas komik Indonesia, mendorong pula hadirnya comicstudies atau kajian akademis atas media komik. Kajian komik masih merupakan bidang baru dalam kajian media, pun di Amerika, negara yang budaya komiknya sudah sangat maju. Kajian komik merupakan pembacaan atas suatu karya komik, yang dilakukan dengan berbagai metodologi, menunjukkan pendekatan yang berangkat dari banyak pilihan disiplin yang telah ada sebelumnya seperti Sejarah Seni, Literatur, Kajian Budaya dan Media, Kajian Gender dan Etnik, Sosiologi, Antroplogi, Ekonomi, kadang disebut cergam, comix, bande desinee, sequential art, atau graphic-storytelling.

Untuk penelitian kali ini, penulis mencoba berkilas balik dengan mengambil objek kajian seri komik Gundala hasil karya Hasmi atau Harya Sura Minata, yang sempat merajai puncak popularitas pada periode pertengahan 1970-an hingga awal 1980-an. Gundala dipilih karena hingga hari ini, masih banyak orang dari penggiat komik sampai dengan masyarakat awam yang masih mengenal Gundala, namun hanya sebatas mengenal sosoknya sebagai superhero lokal dan abai mengenai kualitas estetika komiknya. Komiknyapun tidak banyak dikembangkan sejak terakhir kali terbit tahun 1983, dan hanya beberapa kali penerbitan ulang dengan remaster tahun 2005.

Gundala Putra Petir berkisah mengenai seorang ilmuwan, digambarkan sebagai insinyur bernama Sancaka yang setelah percobaannya yang gagal, justru disambar petir. Hasmi membelokkan plot sciencefiction menjadi 'science-sciencenan' menurut versinya, sehingga kekuatan yang mengubah Sancaka menjadi jagoan bernama Gundala tidak lagi ilmiah, namun lebih berkesan klenik, mistik dan supranatural. Kaisar Kronz 
yang mengangkat Sancaka menjadi anaknya, memberinya kekuatan petir dan kemampuan berlari secepat pesawat, sering diidentikkan dengan Ki Ageng Selo, sosok penguasa petir dalam kepercayaan Jawa. Ketika berubah pun Sancaka tinggal membuka liontin kalungnya, yang secara mistis mengeluarkan sosok 'seragam' Gundala, tanpa perlu penjelasan ilmiah atau bersusah payah bersembunyi dan membuka baju ala Superman (Bajraghosa, 2012: 6-7).

Beberapa situs dan artikel majalah yang membahas komik, menempatkan Gundala menjadi salah satu karakter komik yang paling dikenal hingga kini, selain Godam, Si Buta dari Gua Hantu, dan Panji Tengkorak. Kondangnya karakter ini dibuktikan dengan diangkatnya Gundala ke layar lebar oleh Lilik Sudjio melalui film berjudul Gundala Putra Petir dengan Gundala/ Sancaka yang diperankan oleh Teddy Purba. Gundala hingga kini dicatat sebagai komik superhero Indonesia yang kedua dan terakhir difilmkan setelah Sri Asih (1954), walaupun naskah film tidak 100\% diterjemahkan dari naskah komik. Pendapat ini didapat dengan memperhitungkan film Panji Tengkorak (1971) dan sederet jagoan silat lain sebagai adaptasi dari komik silat. Sosok Gundala juga pernah muncul sebagai bintang iklan produk balsem, walaupun warna kostumnya diubah menjadi ungu (Bajraghosa, 2012: 6-7). Buku Kronologi Gundala (Wijaya, 2013) mencatat seri Gundala Putra Petir telah terbit hingga 23 buku mulai dari tahun 1969 hingga tahun 1982, dan disusul dengan komik strip di tahun 1988.

Apresiasi atas komik Gundala ini sudah selayaknya ditingkatkan dengan menempatkan seri ini dalam ranah kajian akademis, yang diharapkan dapat menunjukkan estetika komik Gundala sebagai sebuah kreasi karya seni rupa, dan untuk menilik warisan gaya sebagai dorongan dan pembelajaran untuk industri komik Indonesia saat ini. Berdasarkan latar belakang yang telah dikemukakan, didapatkan rumusan masalah sebagai berikut. Seperti apa Dinamisme Sekuensial dihadirkan pada komik Gundala. Seperti apa dinamisme sekuensial yang dihadirkan mendukung naratologi komik Gundala.

\section{Penelitian}

Dinamisme Sekuensial dikenalkan oleh Andre Molotiu (dalam Duncan \& Smith, 2012: 87-100) untuk melihat suatu halaman komik sebagai sebuah karya seni rupa yang mempertimbangkan estetika visualnya, dan dalam tataran narasi, ia tetap menyampaikan pesannya. Dinamisme sekuensial pada awalnya ia temukan pada komik-komik 
abstrak, di mana bentuk-bentuk yang ada sepenuhnya mewakili bentuk itu sendiri, dan bukan representsi tokoh atau setting dalam dunia cerita layaknya pada komik naratif. Dinamisme Sekuensial menaruh perhatian pada kedinamisan dari kuasa yang akan memandu mata pembaca melintasi dan melewati sebuah sekuen pada sebuah plot, suatu elemen grafis yang memandu pembaca dari satu panel ke panel berikutnya (Molotiu dalam Duncan \& Smith, 2012: 87-100).

Cara penelitian ini diturunkan dari buku Critical Approaches to Comics; Theories and Methods, pada tulisan Molotiu (dalam Duncan \& Smith, 2012 87-102) terkait Dinamisme Sekuensial pada komik, yang mengandung beberapa hal sebagai berikut.

\section{a. Bahan}

Sampel penelitian akan mengarah pada bingkai-bingkai panel dalam beberapa buku komik Gundala, seri ‘Gundala Cuci Nama’.

b. Prosedur Pelaksanaan dan Cara Analisis data

Pelaksanaan penelitian dilakukan dalam beberapa tahap sesuai yang telah dirumuskan oleh Andrei Molotiu untuk mengamati dinamisme sekuensial pada halamanhalaman komik. Tahap awal yaitu memilah panel-panel tertentu yang dianggap memiliki dinamika secara estetika, dengan mengabaikan muatan naratifnya. Pada tahap ini panel-panel yang memuat obejk utama yang berurutan secara dinamis dipilih untuk kemudian dikaji pola pergerakannya secara visual.

Tahap kedua adalah membahas secara visual muatan-muatan yang ada panel-panel terpilih dari segi bentuk, bukan sebagai representasi diegetik dunia cerita. Pada tahap ini objek yang ada dalam panel dijelaskan posisinya, sudut pengambilan gambarnya dan dengan dramatisasi seperti apa objekobjek tersebut dihadirkan.

Tahap ketiga adalah melihat tipe-tipe sekuensial melalui pemahaman enkapsulasi. Tipe sekuensial yang dimaksud adalah melihat pola hubungan antar panel bagaimana objek ditempatkan pada suatu panel dan bagaimana objek tersebut dimunculkan lagi pada panel selanjutnya. Misal ada pola yang muncul, akan didata dan dianalisa; misal trajectory atau lintasan geraknya membentuk suatu bentuk geometris, parabol, segitiga, atau mengarah pada lintasan diagonal, atau dihadirkan secara simetris, terbalik dengan panel sebelumnya.

Tahap berikutnya adalah mempertemukan pembahasan dinamisme sekuensial secara bentuk dengan muatan narasinya. Pola-pola 
sekuensial yang hadir pada analisa tahap sebelumnya dipertemukan kembali dengan plot utama dari keseluruhan kisah adegan di mana terdapat panel-panel tersebut. Pada bagian ini, dinamisme sekunsial dilihat perannya dalam menghadirkan keseluruhan narasi.

Kesimpulan diharapkan dapat ditarik dari hadirnya tipe-tipe bentuk sekuensial yang dinamis dan mempunyai korelasi yang erat dengan penceritaan dalam bentuk visual.

\section{HASIL PENELITIAN}

\section{Analisis Sampel}

Sampel yang akan dianalisa ada di antara halaman 20-29 Gundala Putra Petir, seri “Gundala Cuci Nama” jilid 2 karya Hasmi, yang menampilkan adegan pertarungan Gundala asli melawan Gundala palsu. Momen ini menjadi penting karena hadirnya musuh dengan kekuatan identik selalu menjadi bagian tidak terpisahkan pada kisah komik superhero, terlebih apabila keduanya juga memiliki penampilan yang identik. Analisa pada seri ini akan mengamati beberapa unit spread tiap dua halaman yang berurutan, alih-alih mengamati halaman tunggal.

Pada spread halaman 20-21, masingmasing halaman menampilkan pola pembagian panel yang sama: setiap halaman tersusun atas dua lajur sama besar atas-bawah dengan bagian atas memuat 1 panel atas utuh selebar halaman, sedang bagian bawah memuat panel 2 kolom. Secara tata letak, spread ini menampilkan susunan panel yang simetris antar halaman, simetris pada masingmasing halaman, dan lebih menarik lagi jika melihat muatan masing-masing panel yang juga memiliki kesan simetris. Kedua panel bagian atas menampilkan close up wajah bertopeng Gundala, yang pada halaman 20 muncul di antara dedaunan didampingi dengan wajah Maza di kiri dan wajah Godam di sebelah kanan, sedangkan di halaman 21 wajah bertopeng Gundala tampil sendiri.

Kedua panel bagian bawah halaman 20 juga memiliki muatan yang sama: sosok Gundala, meskipun ditampilkan dengan arah yang berbeda. Panel sebelah kiri sosok Gundala dihadirkan dengan tubuh tertekuk menghadap kiri, sedangkan di panel sebelah kanan Gundala dengan posisi berjalan menuju ke kanan. Bagian bawah halaman 21 juga memuat objek yang sama: wajah Gundala. Panel sebelah kiri wajah Gundala tampak depan dengan mata melotot, sedangkan panel sebalah kanan menampilkan wajah Gundala dari sisi sebelah kiri yang sedang melirik ke sudut mata sebelah kiri. 

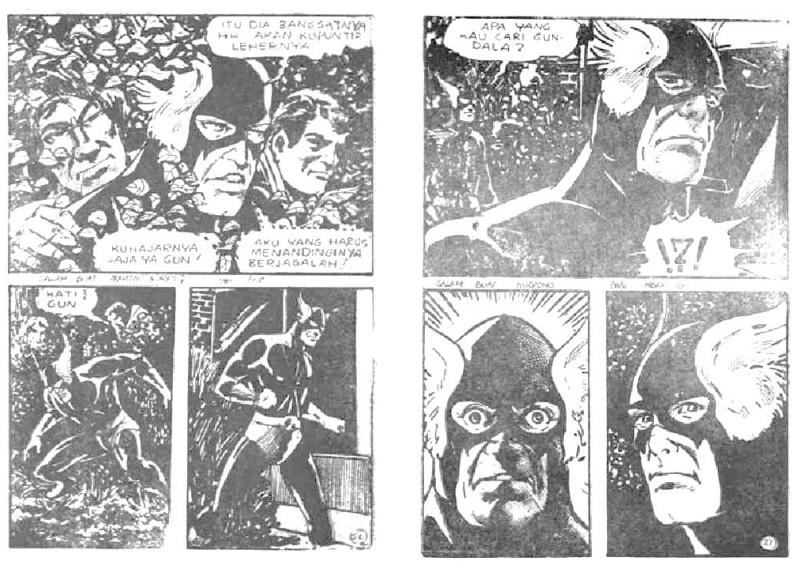

Gambar 1 Bentangan hlm 20-21.

Bentangan (spread) halaman pada komik selain dibaca per halaman, keseluruhan dua halaman ini bisa juga dibaca sebagai satu kesatuan. Spread hlm. 20-21 menunjukkan pola lay out yang simetris, baik bingkai panelnya maupun muatannya.

Pada spread halaman 24-25 menampilkan pembagian ruang panel yang identik, setiap halaman memuat 2 panel yang berukuran sama atas-bawah. Halaman sebelah kiri pada panel atas menampilkan sosok Gundala yang melompat menuju Gundala lainnya yang digambar membelakangi pembaca di bagian tengahkanan panel. Lintasan arah loncatan ini menuju ke arah pembaca, yang diperjelas pada panel lanjutannya dengan Gundala yang semakin dekat dan kaki kanannya membentur pada sosok Gundala satunya yang semakin tersudut ke arah kanan panel. Halaman 25, sebelah kanan, pada panel atas ditampilkan sosok Gundala yang terpojok di sebelah kiri panel karena diserang oleh Gundala lainnya. Gundala yang berada di sebelah kiri, pada panel bawah ditampilkan terjatuh dan Gundala yang satunya ditunjukkan bersiap menyerang kembali di bagian kanan.
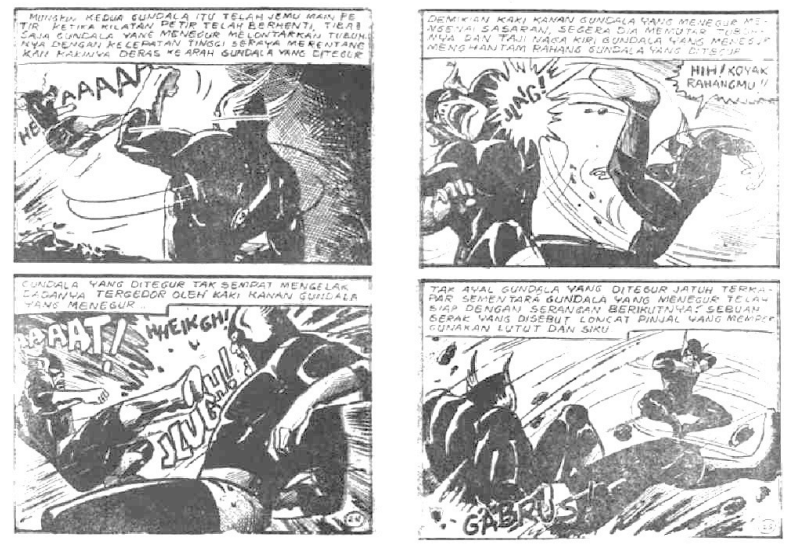

Gambar 2 Bentangan (spread) halaman 24-25.

\section{Dinamisme Sekuensial dan Fungsi Narasi}

Dinamisme sekuensial pada spread 20-21 dihadirkan dengan menampilkan kehadiran sosok Gundala asli dan Gundala Palsu yang secara berurutan selang-seling tiap panel: aslipalsu-asli-palsu-asli-palsu. Menariknya, meskipun tiap unit halaman menghadirkan komposisinya sendiri, komposisi keduanya sebagai unit spread juga menghadirkan sensasi yang berbeda. Menurut Groensteen (2007: 35-36), dengan mempertimbangkan sifat saling mempengaruhi antar halaman tunggal dalam sebuah tampilan halamanganda, akan memberi banyak kemungkinan manfaat (secara naratif dan bentuk). Sensasi yang bisa ditelusuri hanya pada format buku ini juga bertujuan untuk memberi penekanan 
pada hadirnya Gundala asli dan/atau Gundala Palsu, dengan menampilkan close up wajah, sosok tubuh, dan kembali ke close up wajah.

Penampilan panel yang berbentuk sama, dengan muatan yang sama mengarahkan pembaca secara naratif pada teka-teki mengenai kehadiran sosok Gundala mana yang ada pada panel tersebut. Asli atau palsu. Pada bagian awal masih bisa ditelusuri sosok yang asli, namun dengan sekuensial yang selang seling dalam panel yang identik menempatkan sekuensi ini sebagai sebuah tahapan yang menuju pada enigma: mana yang asli atau mana yang palsu. Pada halaman selanjutnya, adegan pertarungan, ambiguitas asli-palsu ini menjadi menarik secara kisah karena membiarkan pembaca masih dalam teka-teki namun juga sekaligus menyuguhkan adegan pertarungan yang seru.
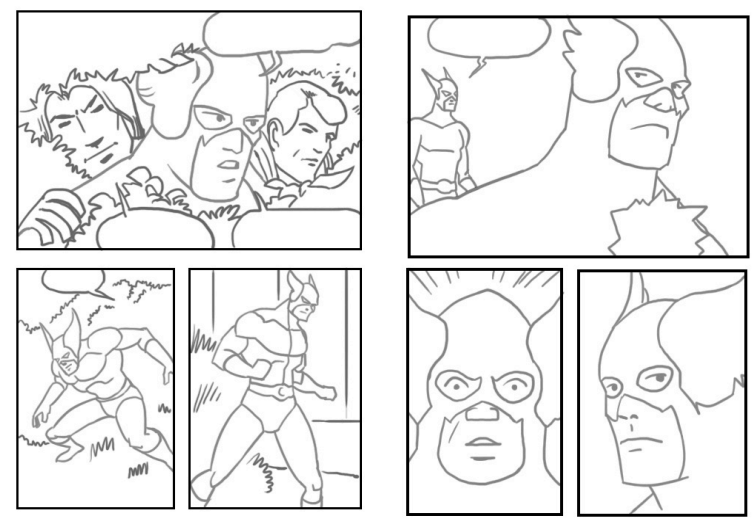

Gambar 3 Bagan hlm. 20-21. Menunjukkan tata letak yang simetris baik satu unit halaman maupun sebagai spread. Muatan yang juga identikal dalam tiap panel yang simetris, menampilkan teka-teki tentang tokoh Gundala Asli atau Gundala Palsu.
Dinamisme sekuensial yang hadir pada halaman 24 menunjukkan urutan aksi dan perpindahan posisi satu Gundala yang menyerang Gundala lainnya. Pola perpindahan panel ini meskipun menyerupai perubahan aksi, namun ternyata lebih dekat pada pola perpindahan momen-ke-momen yang menunjukkan sebuah proses detail dari sebuah kejadian yang terjadi dalam waktu yang singkat. Berbeda dengan halaman 25 yang nyatanya lebih dekat pada pola perpindahan aksi-ke-aksi. Meskipun terjadi dalam waktu yang kurang lebih sama singkatnya, akan tetapi pose aksi dari masingmasing karakter lebih terasa dominan perubahannya.

Diamati sebagai sebuah unit spread, Dinamisme sekuensial yang dihadirkan adalah inversi atau pembalikan yang menempatkan tengah halaman sebagai porosnya. Sebuah poros semu yang hadir mengiring pola tata letak panel. Poros semu ini bisa dimaksudkan dari sejak awal rancangan karya komik, maupun bisa dilihat sebagai sebuah cara membaca komik yang ditemukan sendiri oleh pembaca.

Inversi dapat dilihat melalui posisi Gundala yang menerima serangan, digambar lebih dekat kepada pembaca (sehingga representasinya lebih besar daripada Gundala yang menyerang), berada pada, dan/atau 
mendekati poros. Sehingga meskipun gambarnya tidak identikal, namun berdasar pada cara penggambaran (tersudut/ terserang, menyerang) dan representasi ukuran gambar yang ada (besar, sedang), halaman sebelah kiri seolah seperti pembalikan dari halaman sebalah kanan. Inversi ini menambah manfaat yang bisa dihadirkan melalui format terbitan yang berupa buku. Secara naratif tata letak ini menyumbang kesan sosok yang tersudut pada satu bidang yang sama (poros tengah).

Sedangkan teka-teki sosok Gundala Asli atau Palsu masih dipertahankan dalam pertarungan ini. Caption yang ada pada kotak narasi mengarahkan kedua sosok Gundala secara berbeda, namun tidak secara jelas dan gamblang menunjukkan mana yang asli dan palsu. Pembaca diajak menikmati pertarungan tanpa perlu memihak pada satu tokoh tertentu.

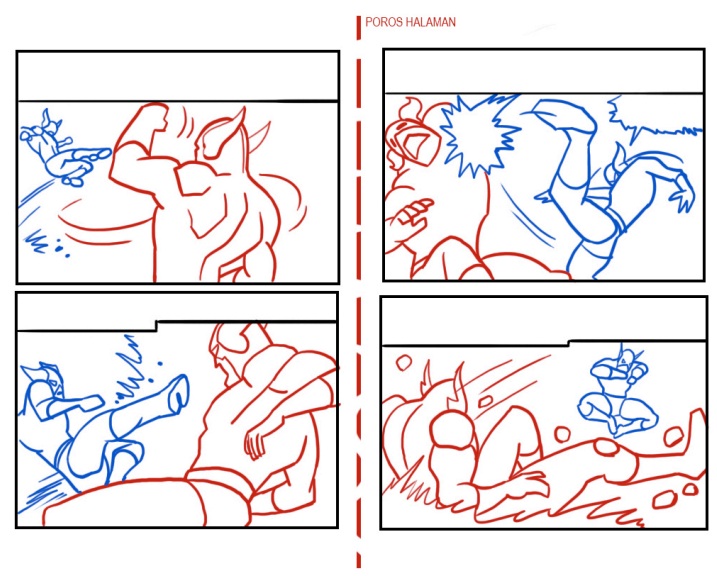

Gambar 4 Bagan hlm. 24-25.

Poros semu tengah halaman yang menjadi lokasi salah satu karakter dalam pertarungan yang tersudut. Istilah sudut menjadi harafiah dalam tata letak ini.

\section{KESIMPULAN}

Setelah dilakukan analisa sampel dan pembahasan, didapatkan beberapa kesimpulan berikut terkait dengan dinamisme sekuensial pada komik Gundala.

Dinamisme sekuensial pada dasarnya tetap hadir pada komik yang bersifat naratif melalui hubungan antar panel atau antar halaman yang diperhitungkan dengan baik komposisinya. Pada komik Gundala yang secara umum hanya menghadirkan dua panel sama besar pada setiap halaman seperti kebanyakan pada komik sejenis di masanya, nyatanya tetap mampu memiliki dinamisme sekuensial. Dinamisme sekuensial pada komik Gundala hadir melalui penataan muatan pada panel, seperti gambar sosok manusia dengan pose dan aksi tertentu, yang bila berurutan dengan panel lainnya dengan pose dan aksi lainnya mampu menunjukkan arah gerak, atau aksi.

Antar panel dapat disusun secara simetris, memiliki bentuk muatan yang mirip dengan beberapa perbedaan, untuk menghasilkan kesan gerak atau perubahan aksi. Antar halaman dapat dimanfaatkan, terutama yang hadir dalam bentuk bentangan atau double page, dengan mempertimbangkan keterpengaruhan baik cerita maupun komposisi sehingga dapat dilihat sebagai satu kesatuan skuensial yang tidak terputus 
meskipun beda halaman. Tata letak dapat menghadirkan panel-panel yang disusun secara simetris maupun isi muatan panel yang seolah berupa pembalikan atau saling silang untuk menghasilkan komposisi visual yang lebih menarik.

Penataan komposisi yang dimaksud pada akhirnya tetap dihubungkan dengan naratologi sebuah komik, yang mengarah pada kesuksesan sebuah penyampaian kisah kepada pembaca.

Kedigdayaan Gundala sebagai superhero, nyatanya mampu ditandingi oleh Ki Wilawuk yang tidak bisa kalah, atau mati karena mempunyai ilmu hitam. Hal ini memang muncul melalui balon kata atau narasi, namun dengan urutan panel yang baik hal tersebut juga mendapat penekanan. Kekalahan dan kehancuran Ki Wilawuk, seperti sudah di depan mata pembaca yang hadir melalui dua panel yang menunjukkannya tersengat petir Gundala dan jatuh terpuruk, namun di panel selanjutnya, halaman berikutnya, sosoknya sudah berdiri kembali. Sekuensi yang ada seolah turut membangkitkan sosok Ki Wilawuk.

Begitu pula dengan keadaan Gundala yang terkaget dengan ilmu Ki Wilawuk dan lengah sehingga menjadi bulan-bulanan ditunjukkan dengan komposisi panel yang berurutan dengan muatannya yang mempunyai arah lintasan saling menyilang. Silang pertama milik Ki Wilawuk yang menghunjam secara semi diagonal dengan kekuatan penuh ke sosok Gundala. Sedang silangan kedua milik Gundala yang dengan sisa tenaga yang ada hanya mampu menghindar dari serangan ki Wilawuk.

Pada adegan pertemuan Gundala asli dan Gundala Palsu, komposisi panel dibikin simetris pada tiap halaman, dan juga pada bentangan halaman ganda. Dengan isi muatan panel yang mirip dan diulang berurutan; wajah Gundala asli lalu wajah Gundala palsu, sosok Gundala asli lalu sosok gundala palsu, dan kembali ke wajah -wajah Gundala yang kemudian dibuat sedemikian rupa seperti mengacak, sehingga pembaca turut menebak mana yang asli dan yang palsu. Narasi yang ada bersifat menjelaskan pertarungan, namun tidak menyebutkan mana yang Gundala asli dan mana yang Gundala tiruan. Bahkan dalam suatu panel, disebutkan kawan-kawan Gundala yakni Maza dan Godam turut bingung ketika hendak memberi bantuan.

Komposisi muatan panel pada adegan pertarungan antar Gundala kembar yang juga hadir melalui bentangan halaman-ganda dibuat seperti pembalikan, yang menjadikan lipatan tengah halaman sebagai porosnya. Pada poros ini satu Gundala terpojok, baik di 
halaman kiri maupun halaman kanan. Dengan membaca narasi yang menyertai, pembaca bisa tahu Gundala mana yang terpojok. Namun secara komposisi, berupa sekuensi sosok-sosok Gundala yang baku hantam, yang seperti di-flip pada halaman berikutnya, dapat dilihat bahwa sebenarnya pembaca tetap dibuat pada posisi yang masih menebak, mana Gundala yang asli dan yang palsu.

Dinamisme sekuensial yang dihadirkan melalui wahana panel, urutan antar panel, hingga komposisi suatu halaman, nyatanya mampu mendukung jalannya cerita komik dan mampu menjadikan tiap-tiap panel sebagai unit yang hidup.

Sebagai penutup, kehadiran dinamisme sekuensial perlu dipertimbangkan dalam pola kreasi komik untuk semakin menegaskan bahwa komik Indonesia pada perkembangan terkini, lebih menekankan diri sebagai media bercerita. Melalui dinamisme sekuensial inilah sisi komposisi bisa bertemu dengan sisi narasi dengan baik.

\section{DAFTAR PUSTAKA}

[1] Duncan, Randy \& Matthew J. Smith. (2009), The Power of Comics; History, Form and Culture. Continuum, New York

[2] (2011), Critical Approaches to Comics; Theories and Methods, Routledege, New York

[3] Eisner, Will. (2004), Comics and Sequential Arts, Poorhouse Press, Florida.

[4] Endraswara, Suwardi. (2003), Metodologi Penelitian Kebudayaan, Gadjah Mada University Press, Yogyakarta

[5] Hasmi. (1967), Gundala Cuci Nama, Prasida, Jakarta

[6] McCloud, Scott. (2001), Understanding Comics; Invisible Arts atau Memahami Komik, Kepustakaan Populer Gramedia, Jakarta.

[7] - (2008), Reinventing Comics atau Menciptakan Kembali Komik, Kepustakaan Populer Gramedia, Jakarta 